\title{
Delivery and fate of fluvial water and sediment to the sea: a marine geologist's view of European rivers*
}

\author{
JOHN D. MILLIMAN \\ School of Marine Science, College of William and Mary, Gloucester Pt, VA 23062 USA.
}

\begin{abstract}
SUMMARY: Despite their relatively small drainage areas, European rivers reflect a wide variety of hydrologic regimes, although with very few exceptions they have been strongly affected by human activity. Scandinavian rivers (particularly those draining Iceland and western Norway) can have high runoff, and, except for those draining Iceland, all have very low suspended and dissolved sediment loads. Northern and western European rivers have somewhat lower runoff, among the lowest suspended sediment yields in the world, and anthropogenically enhanced dissolved solid loads. Annual discharge of many of these rivers appears to vary inversely with the North Atlantic Oscillation index. Rivers discharging from the southern Alps into the Mediterranean Sea have relatively high runoff, high suspended sediment yields (reflecting younger, more easily erodable rocks as well as generally smaller drainage basins), and high dissolved yields, although presumably with somewhat less human influence. European rivers and their estuaries tend to reflect the terrestrial environments of their drainage basins (i.e. climate, landscape geomorphology, geology), but they also display strong anthropogenic signatures. Sediment erosion increased dramatically in the last several millenia in response to deforestation, farming and mining. In the past 50 years, however, increased soil conservation and local reversion of agricultural land to forest, as well as river diversion and dam construction, have decreased the suspended sediment loads of many European rivers. Improved mining and manufacturing techniques, as well as more effective use of fertilizers and improved waste treatment, almost surely will result in lower dissolved solids and nutrient fluxes to the coastal environments, which presently are the highest in the world. The long-range effects of changed land use on estuarine and coastal environments remain to be seen, although decreased sediment loads in the past 20-40 years have already resulted in increased shoreline erosion. Decreased nutrient fluxes almost certainly will affect water quality in European coastal waters, and decreased silicate delivery by some dammed rivers may result in proliferation of new (and perhaps harmful) estuarine and coastal ecosystems. Everything points to further changes as European rivers and their drainage basins continue to change in the coming years.
\end{abstract}

Key words: European rivers, hydrologic regimes, river runoff, sediment loads, shoreline erosion, anthropogenic signatures.

\section{INTRODUCTION}

Rivers draining Europe are small compared to other parts of the globe. The largest European river, the Danube, for instance, ranks $24^{\text {th }}$ in terms of drainage basin area $\left(824,000 \mathrm{~km}^{2}\right)$; the second largest river, the Rhine $\left(220,000 \mathrm{~km}^{2}\right)$ is $58^{\text {th }}$; and the historic Thames $\left(15,000 \mathrm{~km}^{2}\right)$ is about $600^{\text {th }}$ (data compiled by Milliman and Farnsworth, in press). The Danube, whose pre-dam sediment load was

\footnotetext{
*Received June 12, 2001. Accepted June 27, 2001.
}

about $80 \times 10^{6} \mathrm{t} / \mathrm{yr}$, ranked only $20^{\text {th }}$, behind such relatively unknown rivers (at least to most western scientists) as the Fly, Hualien and Purari.

Despite their small size, European rivers are well known and well documented relative to other global rivers. Few readers of this paper, for instance, are familiar with the Liaohe (China), Ogooue (Gabon) or Olenyok (Russia), even though all have similar sized drainage basins as the Rhine, perhaps in part because they have not been recognized in epic poems or Wagnerian operas. Moreover, because of their proximity to many universities and research 
facilities, European coastal areas have been studied for more than 100 years. English estuaries, for instance, are amongst the most thoroughly documented estuaries in the world, even though collectively English rivers probably discharge less sediment annually than a moderate-sized Chinese river discharges in a single day.

In the aftermath of the Second World War and beginning of the Cold War, an increasing amount of university and national oceanographic effort in both Europe and North America (as well as the former Soviet Union) was devoted to deep-water research, in large part (directly or indirectly) related to marine acoustics: detecting enemy submarines and hiding friendly ones. This bathyal emphasis paid major dividends in terms of our understanding of Earth structure and history. Many of the break-throughs in our understanding of the Earth's geology, in fact, have come from the profusion of post-WW II marine geophysical and geological data. Scrape away the glossy veneer of many innovative paradigms of the late $20^{\text {th }}$ century - plate tectonics, sequence stratigraphy, paleoclimatology - and one finds marine data (magnetic anomalies, seismic profiles, long sediment cores, deep-sea drilling) obtained directly or indirectly for national defense purposes.

Since the1990s, however, two major changes have redirected the oceanographic research once again landward. First, with the end of the cold war, the emphasis on marine acoustics and anti-submarine warfare sharply diminished, supplanted by an increased military interest in shallow-water (e.g., mines) and coastal (e.g., landing water-based troops) environments. Second, there has been an increased societal awareness of coastal waters and their problems - environmental degradation, decreasing fisheries, global warming, etc. To meet the increased interest in the neretic environment, a number of international projects such as GLOBEC (GLbal Ocean ECosystems Dynamics) and IGBP's LOICZ (LandOcean Interactions at the Coastal Zone) have been initiated, but there are also an increasing number of national and regional studies (e.g., France's ECOFER and ECOMARGE; England's ELOISE, and the US NSF MARGINS programs). Yet despite the critical link between land and the coastal ocean, many marine scientists still remain relatively ignorant about terrestrial processes, which is perhaps a bit myopic, since a holistic view of the coastal zone (such as has been taken by LOICZ) considers the land-sea connection as extending to the headwaters of rivers draining into the coastal zone.
In this paper I address the problem of fluvial fluxes of water and sediment to the ocean, in this case emphasizing European rivers, as they should prove the prime interest and focus for many of the readers of this volume. Attempting to convey to a European readership insights about European rivers, however, is a bit like a European attempting to coach an American on how to play baseball. Nevertheless, in this paper I attempt to draw together some data and resulting considerations that may allow interested readers to view their coastal environments in more innovative and holistic ways.

One particularly interesting aspect about European rivers is that although they are relatively limited in geographic extent, they represent a nearly global representation of rivers, ranging from arctic to sub-tropical, low to high runoff, low to high suspended and dissolved loads, and relatively pristine to heavily impacted by human activity. But these rivers and their drainage basins are continually changing, and these changes will undoubtedly have impacts on Europe's coastal and estuarine environments. Some of the changes may be natural (e.g., near-term and long-term climatic oscillations), others might be related to basin-wide changes in landuse or water discharge, and others might be related to human-induced climate change.

\section{RUNOFF AND DISCHARGE PATTERNS}

Precipitation throughout Europe is largely determined by the marine environment and terrestrial topography. Landward movement of warm air coming from the Gulf Stream and the orographic rising and cooling of warm, moisture-laden air, particularly in the Alps, result in widely variable precipitation and runoff (defined as precipitation minus evaporation) throughout Europe (Fig. 1). Meteorological runoff is greatest along the western coasts of Europe (note, for instance, that runoff in the western parts of the British Isles generally exceeds $1 \mathrm{~m} / \mathrm{yr}$, whereas runoff in the east is locally less than 200 mm/yr; Fig. 1). Precipitation is also high in the mountainous regions of southern Europe, as can be seen by comparing runoff with the locations of mountains seen in Figure 2; locally meteorological runoff in the Alps exceeds $3 \mathrm{~m} / \mathrm{yr}$. In contrast, the Mediterranean climate of southern Europe and the continental climate of central Europe are sub-arid, with runoff in southern Spain less than $50 \mathrm{~mm} / \mathrm{yr}$. The orographic influence of the Apennines precipitation undoubtedly is the prime reason that 


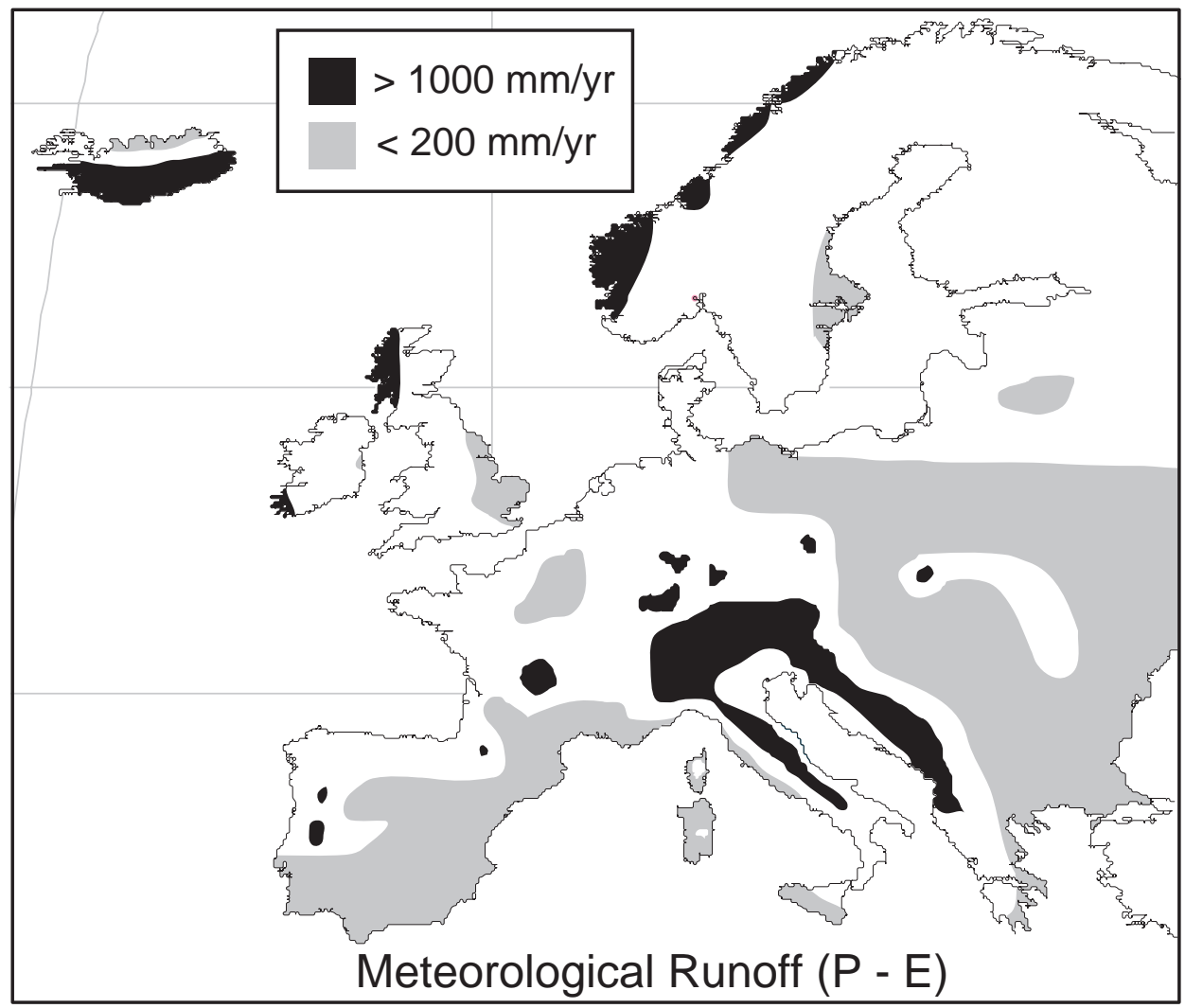

FIG. 1. - Distribution of annual meteorological runoff (P-E) in Europe. Modified from Milliman and Farnsworth (in press).

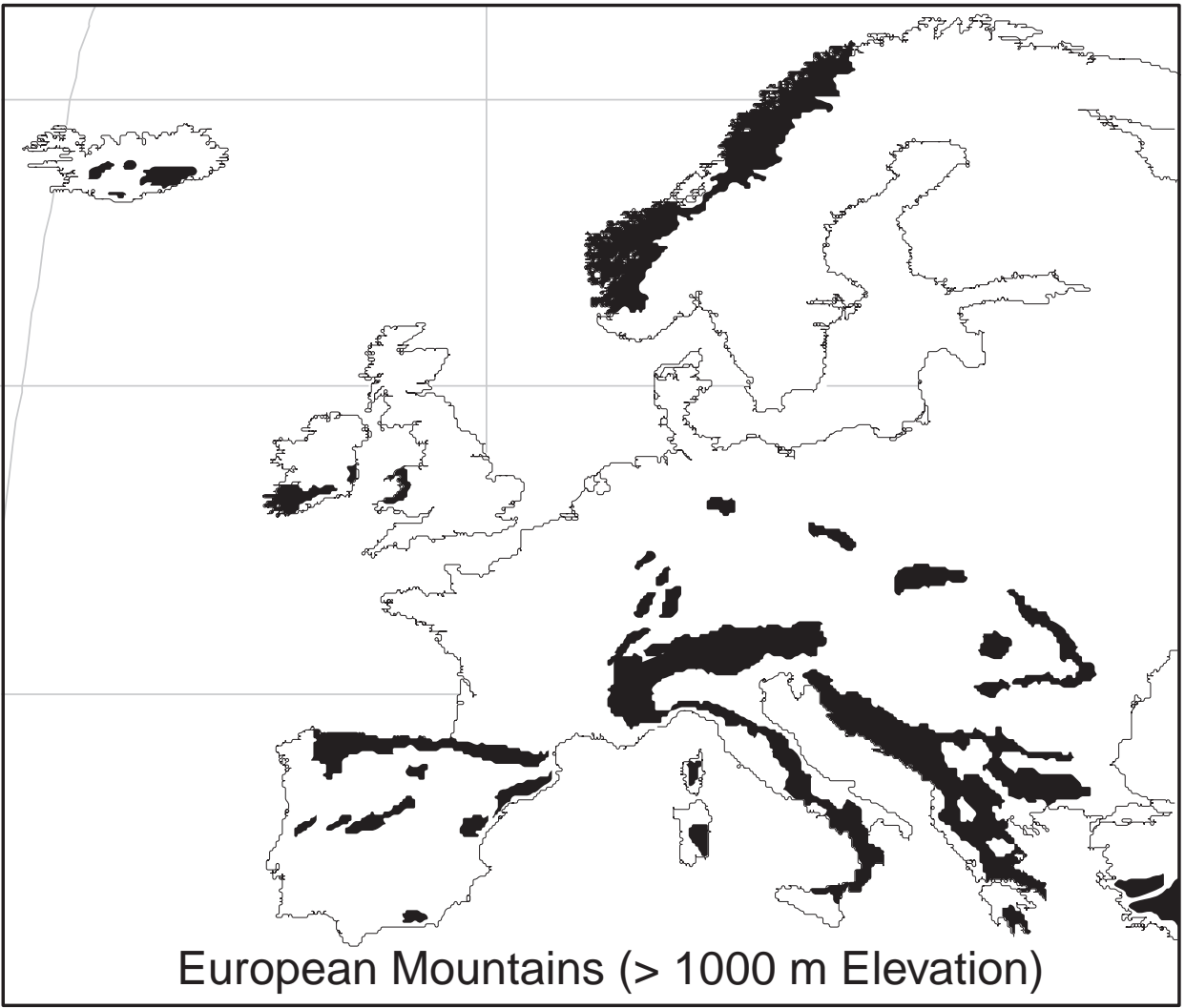

FIG. 2. - Distribution of mountainous terrain in western Europe. Shown in black are elevations higher than $1000 \mathrm{~m}$. Modified from Milliman and Farnsworth (in press). 

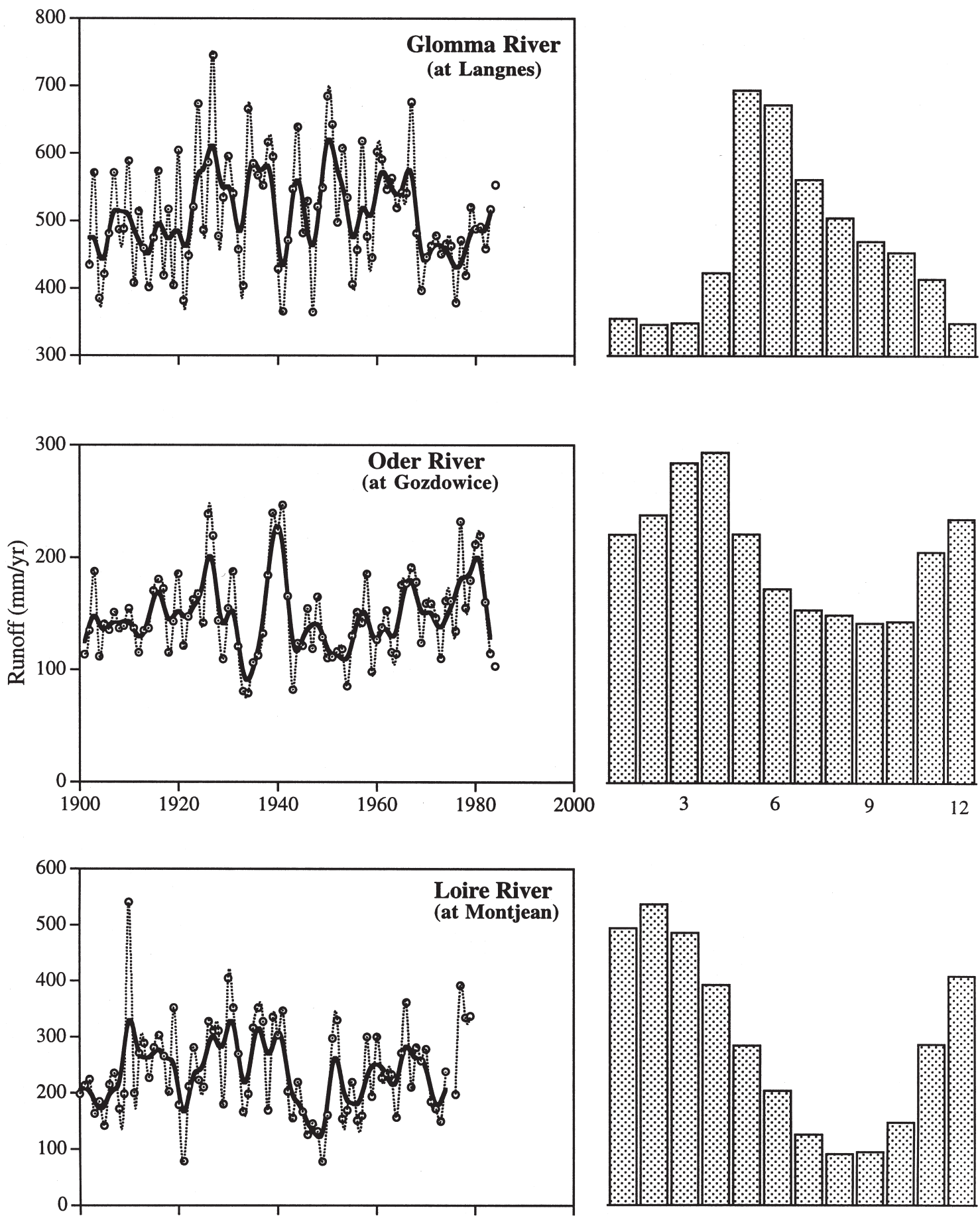

FIG. 3. - Runoff for the Glomma (Norway), Oder (Poland) and Loire (France) rivers in northern and western Europe. To the left are annual runoff values (open circles with dashed lines) as well as running 5-yr means (solid lines). To the left are the monthly variations in discharge. Data from various UNESCO Discharge of Selected Rivers of the World reports.

Italy has much greater precipitation and runoff than elsewhere in southern Europe.

It is therefore not surprising that hydrologic runoff (discharge divided by drainage basin area) is greatest for northern rivers, such as the Glomma (Norway), decreasing substantially in central and western European rivers (e.g., Oder, Loire and
Danube rivers in Figs. 3 and 4). Rivers draining the southern Alps (Ebro and Po in Fig. 4) have somewhat higher runoffs.

Discharge varies temporally as well as spatially. For instance, the Oder, Loire and Danube all exhibited near record-high discharge around 1940 and again in the late 70 s and early 80 s, whereas the Ebro 

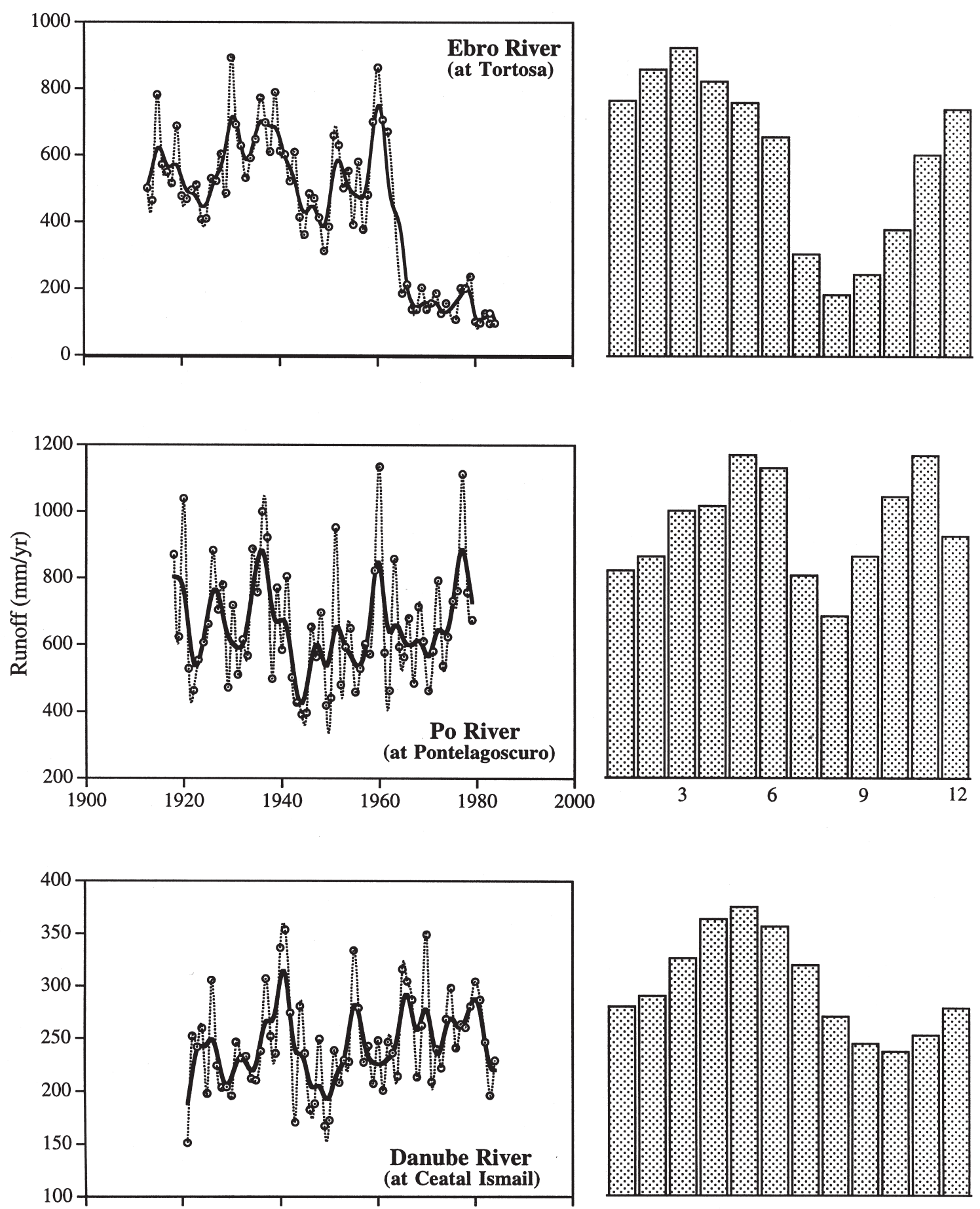

FIG. 4. - Runoff for the Ebro (Spain), Po (Itlay) and Danube (Romania) rivers in southern and eastern Europe. To the left are annual runoff values (open circles with dashed lines) as well as running 5-yr means (solid lines). To the left are the monthly variations in discharge. Data from various UNESCO Discharge of Selected Rivers of the World reports.

and Po had high discharges in the late 30s and 1961, with low discharges in the early 40s and early 60s (Fig. 4). Most interesting, however, is the inverse relationship between discharge of western and central European rivers (Loire and Oder) and the North Atlantic Oscillation (NAO) index, in contrast to eastern US rivers, which show a positive correlation
(Fig. 5). Although the significance of this observation is uncertain, periods of high and low precipitation (and thus river discharge) seem oscillate back and forth across the Atlantic. It is interesting to speculate that inter-annual net freshwater discharge entering the North Atlantic may be roughly constant, but that the relative importance of North 


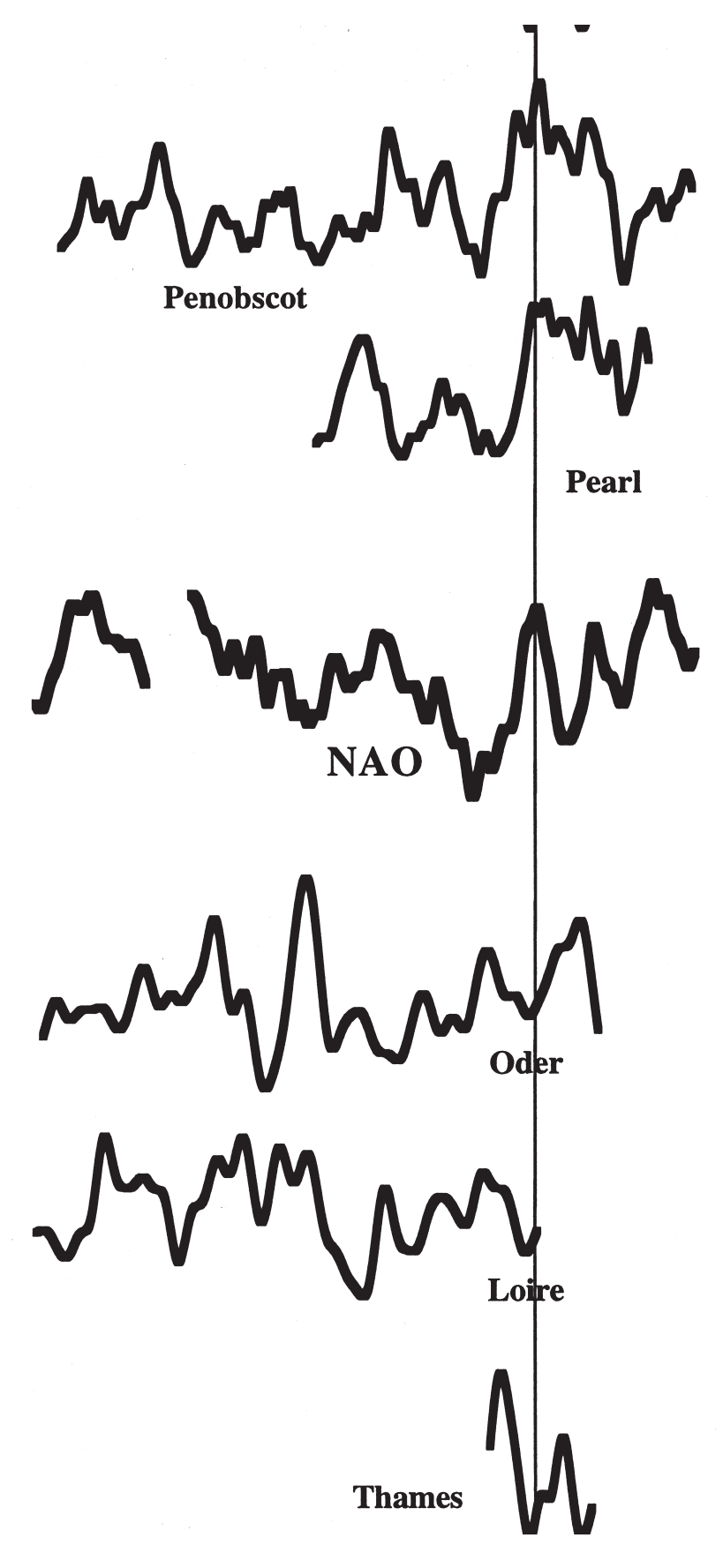

FIG. 5. - Running 5-yr means of runoff for the Penobscot and Pearl rivers (eastern U.S.A) and the Oder, Loire and Thames rivers compared to the North Atlantic Oscillation (NAO) index. Note that positive NAO values tend to coincide with high discharges in eastern US rivers and low discharges for central and western European rivers, whereas low NAO appears related to the opposite trend in eastern US and European rivers.

American vs. western European rivers changes in response to the NAO.

The seasonality of river flow also varies geographically. Scandinavian rivers have minimum discharge during the winter and maximum discharge in mid to late spring. Farther south, the Oder and Loire exhibit highest discharges progressively earlier in the year, and minimum discharges are in the summer months rather than the winter (Fig. 3). The Loire, in fact, displays a Mediterranean climate similar to the Ebro River (high winter runoff, low summer runoff), while the Po and Danube discharge patterns largely reflect the alpine terrain that they drain (Fig. 4).

\section{SOLID AND DISSOLVED LOADS}

The erosion and transport of solid and dissolved sediment are largely a function of climate, geology (reflecting both topography and lithology), and anthropogenic activity. Because of the broad range of climates (particularly precipitation and runoff; Fig. 1), the presence of several major mountain ranges (Fig. 2), the local dominance of both old, hard rocks (e.g., Scandinavia; Fig. 6)) and younger, softer rocks (e.g., southern Alps, and particularly watersheds in central Italy and Albania), and a long history of human activity within many of the drainage basins, European rivers have a wide variety suspended- and dissolved-solid regimes. Fluvial sediment loads are generally related to the topographic relief of the drainage basin, the result of both increased stream gradient and (often) greater tectonic activity (hence landslides). Sediment load also increases with increasing precipitation (Milliman et al., in prep.) and the presence of more erodable rocks (e.g., mudstone compared to granite; Hicks et al., 1996).

Although western Scandinavia is mountainous, eastern Scandinavia is low-lying, and rocks throughout the area are mostly old (pre-Mesozoic) and hard (metamorphic, igneous). As a result, Scandinavian rivers have extremely low sediment loads regardless of basin area (sediment load tends to be a function of basin area, being greater in large than in small drainage basins; e.g., Milliman and Syvitski, 1992). Historically much of Scandinavia has been relatively free of industrial pollution, and this combined with the sub-arctic climate and old (i.e. hard) lithology has resulted in low dissolved loads (Fig. 7, left).

The headwaters for many northern and western European rivers are located in mountainous regions (Fig. 2), but the rocks are generally old (Fig. 2; and therefore hard). Smaller rivers tend to 


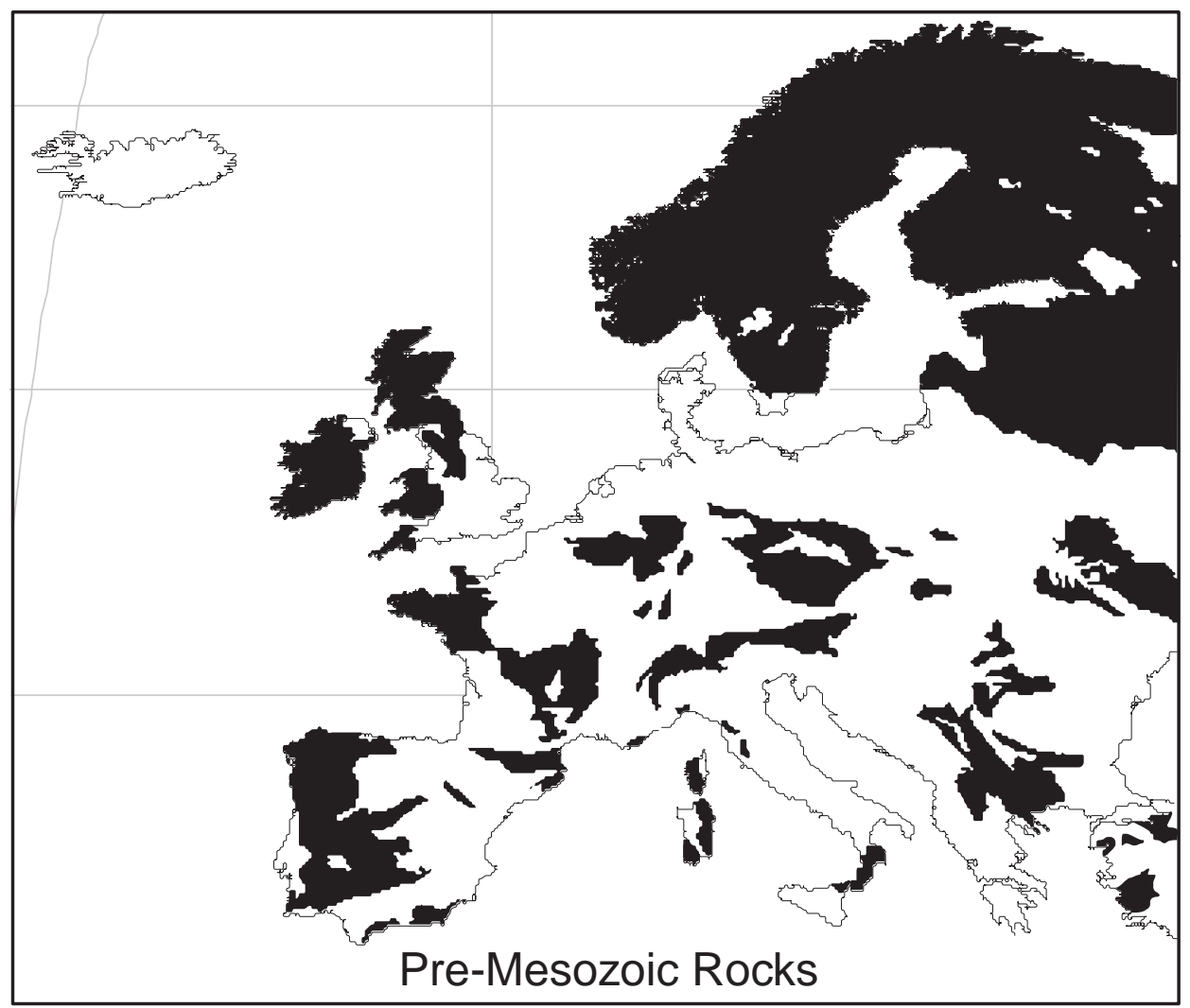

FIG. 6. - Distribution of pre-Mesozoic rocks in Europe. Older rocks here infer that they generally are harder (and thus more difficult to erode) than younger Mesozoic and Cenozoic rocks. After Larsen and Pittman (1985).

drain lower elevations. As a result rivers draining northern and western Europe have low sediment loads, although generally not as low as those for Scandinavian rivers (Fig. 7). (The Rhine provides an interesting anomaly in that much of its sediment load is trapped in Lake Constance, so that north of Switzerland it behaves more like a low- land river than one whose headwaters are in mountainous terrain.) Dissolved loads in western European rivers, however, are not only greater than those in Scandinavian rivers, they loads also tend to be greater than suspended loads (Fig. 7, center), one of the few areas on Earth in which this situation occurs.
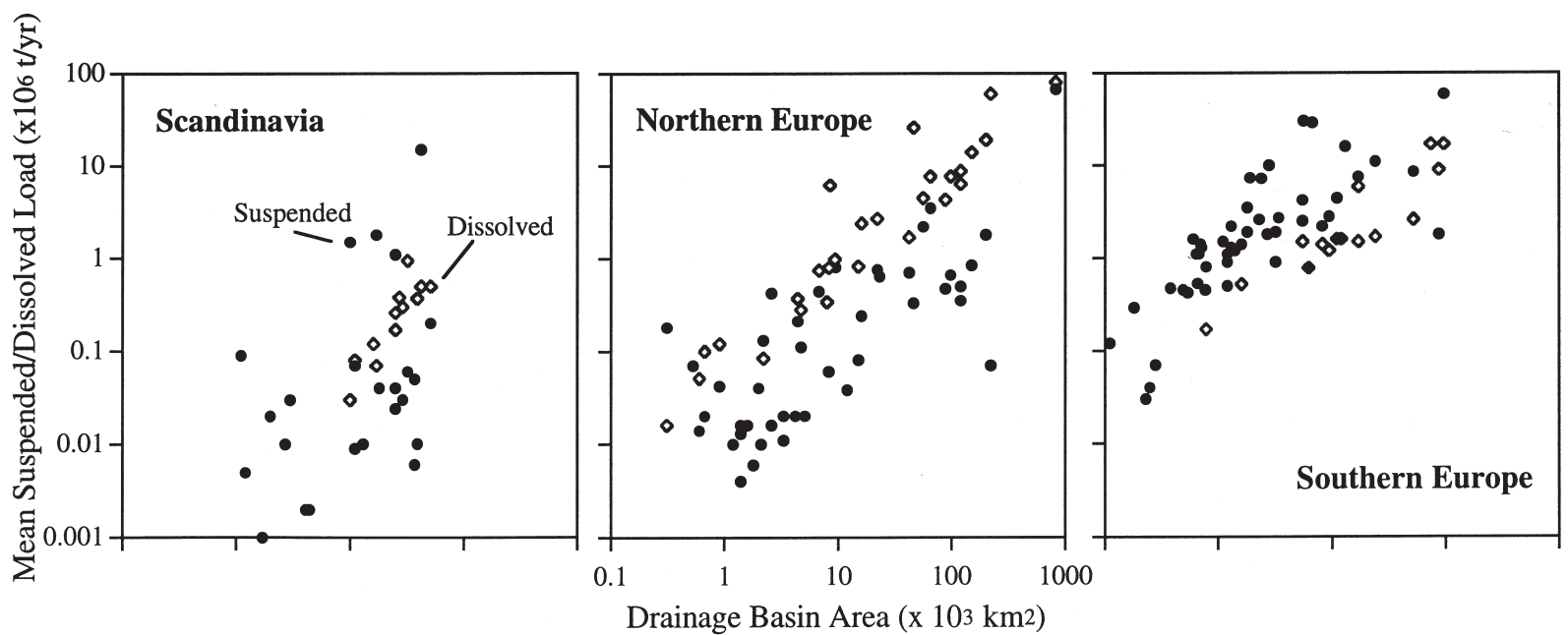

FIG. 7. - Mean suspended and dissolved loads for Scandinavian (left), northern European (center) and southern European (right) rivers. Note that the relation between dissolved (open diamonds) and suspended (solid dots) loads vary regionally. Both suspended and dissolved loads are low in Scandinavian rivers, dissolved loads are substantially greater in northern European rivers, and suspended loads are much greater in southern European rivers. Data from Meybeck and Ragu (1997) and Milliman and Farnsworth (in press). 

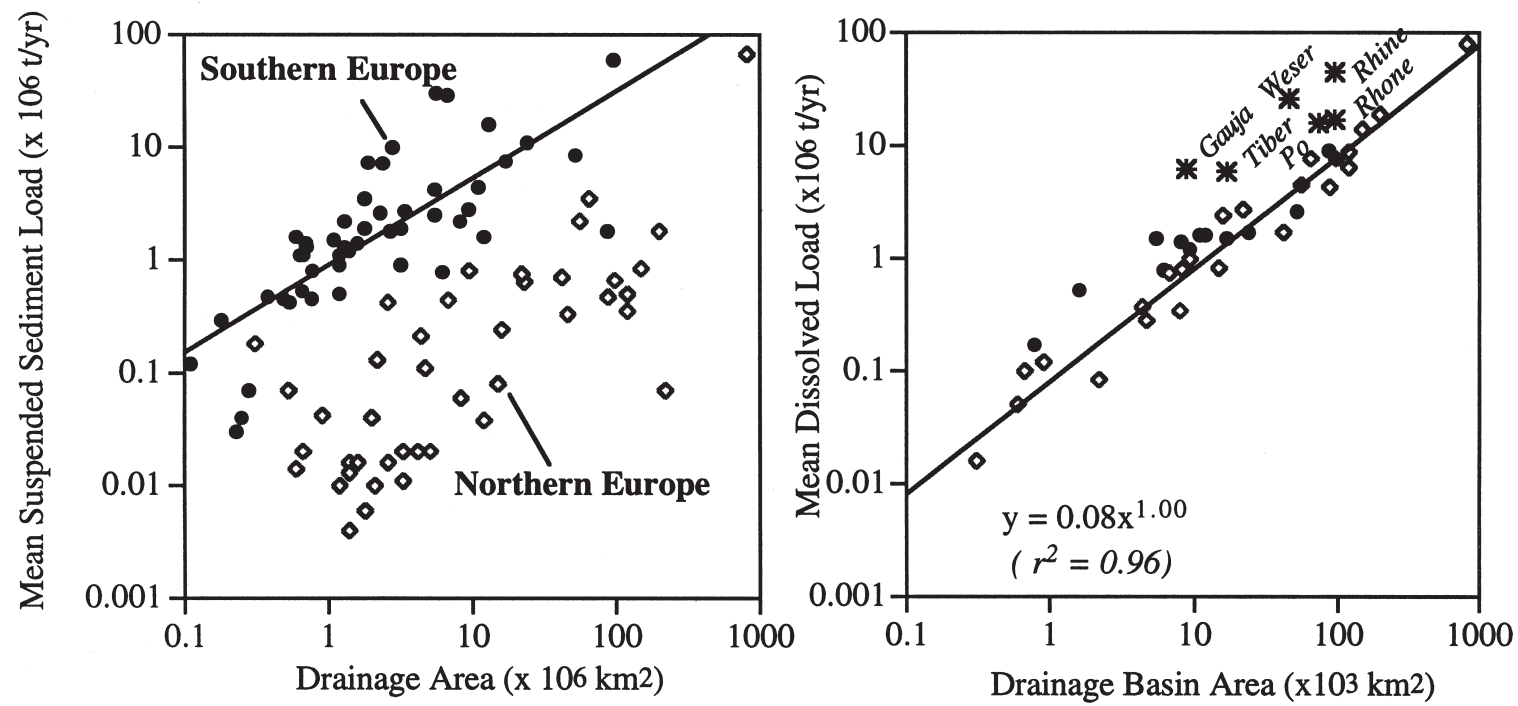

FIG. 8. - Comparison of mean annual suspended loads (left) and dissolved loads (right) for southern (solid dots) and northern (open diamonds) European rivers. Suspended loads for southern European rivers are clearly much greater than they are for rivers draining northward from the Alps, largely the result of regional geology, morphology, and climate. In contrast, the relationship between dissolved load and basin area for northern and southern European rivers is more or less the same, with the main exception of six rivers (Weser, Rhine, Gauja, Tiber, Po and Rhone) whose dissolved loads are substantially greater than their basin area would suggest. See also Table 1.

Most southern European rivers, in contrast, carry sediment loads that are one to three orders of magnitude greater than similar sized rivers draining northern Europe (Figs. 7, right, and 8). Many of the drainage basins draining the southern Alps (and the Apennines in Italy) contain younger (and therefore more erodable) rocks. But the greater sediment loads of southern European rives also reflect a long history of anthropogenic activity on the alpine and Mediterranean landscape (e.g., Woodward, 1995). Southern European river dissolved loads are much less than their suspended loads (Fig. 7), but are similar to northern European rivers (Fig. 8).

It is interesting to note that total dissolved loads TDS) in northern and western European rivers increase essentially linearly as a function of basin size (dissolved load $=(0.08) *(\text { basin area })^{\wedge} 1.03\left(r^{2}=0.92\right)($ Fig. $8)$. If three rivers with anomalously high TDS values (Rhine, Weser and Gauja) were deleted from the correlation, the exponent would $1.00\left(r^{2}=0.96\right)$. Southern European rivers cluster around this correlation except for three rivers -the Tiber, Po and Rhone- who have considerably high TDS values than would be predicted from their basin size. Given the tight fit of the data, in fact, one can calculate theoretical dissolved loads and compare them to measured loads. As inferred from Fig. 8, the measured loads of the Rhine, Weser, Gauja, Rhone, Po and Tiber (shown as asterisks in Fig. 6B) are significantly greater than their basin areas would indicate (Table 1). For European rivers this often is a result of salt mining (e.g., Fraser et al., 1995), suggesting that calculated delivery of dissolved $\mathrm{NaCl}$ and $\mathrm{KCl}$ might account for much of the "excess" dissolved solids in these anomalous six rivers.

Assuming for the moment that all the $\mathrm{Cl}$ is derived from dissolved $\mathrm{NaCl}$, one can calculate the total amount of dissolved $\mathrm{NaCl}$ delivered by each of the rivers. This assumption, of course, is incorrect, since some $\mathrm{Cl}$ is derived from sources other than halite; therefore the calculated numbers in Table 1 must be considered maximum values. Nevertheless, dissolved $\mathrm{NaCl}$ can account for most (if not all) of the excess dissolved solids in the Weser and Rhine rivers (Table 1), but practically none of the dissolved solids in the Gauja or (more importantly) in the three rivers draining the southern Alps. The apparent lack of halitederived $\mathrm{Cl}$ in these southern rivers suggests that these rivers may be less polluted (at least interms of salt) than the northern rivers, and therefore that natural TFDS values are greater than for similar sized rivers in the north. This is reconfirmed by the $\mathrm{Cl}$ to $\mathrm{SiO}_{2}$ ratio, the latter value assumed to be a natural dissolved constituent ${ }^{(1)}$. Northern rivers tend to have significantly greater dissolved $\mathrm{Cl} / \mathrm{SiO}_{2}$ ratios (mean = 37 ; range $=2.1-308$ ) than southern rivers $($ mean $=5.5$; range $=4.5-6.5$ ), and the heavily industrialized hinterlands in Germany have some of the highest $\mathrm{Cl} / \mathrm{SiO}_{2}$ ratios (33, 43 and 308 for the Rhine, Elbe, and Weser rivers, respectively) noted in global rivers.

${ }^{1}$ It should be cautioned that $\mathrm{SiO}_{2}$ contents in dammed rivers can be depleted when trapped in artificial lakes for prolonged periods (Humborg et al., 1997). 
TABLE 1. - Measured and calculated mean annual dissolved solid loads from various European rivers. Calculated values were based on the equation derived in Fig. $6 \mathrm{~B}$ [dissolved load $=(0.08) \mathrm{x}$ (basin area in thousand of $\left.\mathrm{km}^{2}\right)$ ]. NaCl load was computed assuming that all $\mathrm{Cl}$ discharged from the various rivers is associated with $\mathrm{Na}$; clearly this calculated load is a maximum, since the $\mathrm{Cl}$ has other sources. The first six rivers fall upon the curve shown in Fig. 6B and therefore are assumed to have dissolved loads "normal" for European rivers. Measured and calculated are generally similar, and the slight excess measured load for four of the rivers can be explained in large part by dissolved $\mathrm{NaCl}$ The second six rivers have anomalously high dissolved loads (Fig. 6B). Essentially none of the Gauja's (Estonia) excess dissolved load is present as $\mathrm{NaCl}$, whereas all of the Rhine and Weser's excess loads can be explained by dissolved NaCl. In contrast, little of the "excess" dissolved loads from the last three rivers, who drain the southern slopes of the Alps, appear to be derived from dissolved NaCl, suggesting that these high dissolved loads may have less anthropogenic influence than the Rhine or Weser. Measured TDS data from Meybeck and Ragu (1997).

\begin{tabular}{|c|c|c|c|c|c|}
\hline River & $\begin{array}{l}\text { Basin Area } \\
\left(\mathrm{x} 10^{3} \mathrm{~km}^{2}\right)\end{array}$ & $\begin{array}{l}\text { Meas. TDS } \\
\left(\mathrm{x} 10^{6} \mathrm{t} / \mathrm{yr}\right)\end{array}$ & $\begin{array}{l}\text { Calc. TDS } \\
\left(\mathrm{x} 10^{6} \mathrm{t} / \mathrm{yr}\right)\end{array}$ & $\begin{array}{c}\mathrm{D} \\
\left(\mathrm{x} 10^{6} \mathrm{t} / \mathrm{yr}\right)\end{array}$ & $\begin{array}{l}\mathrm{NaCl} \text { Load } \\
\left(\mathrm{x} 10^{6} \mathrm{t} / \mathrm{yr}\right)\end{array}$ \\
\hline Elbe & 150 & 14 & 12 & 2.0 & 6.6 \\
\hline Seine & 65 & 6.3 & 5.2 & 1.1 & 0.8 \\
\hline Guadaliquivir & 56 & 5.9 & 4.5 & 1.4 & 1.9 \\
\hline Ebro & 87 & 9.0 & 7.0 & 2.0 & 2.0 \\
\hline Arno & 8.2 & 1.4 & 0.7 & 0.7 & 0.3 \\
\hline Evros & 52 & 2.6 & 4.2 & (1.6) & 0.4 \\
\hline Gauja & 8.9 & 6.2 & 0.7 & 5.6 & 0.02 \\
\hline Weser & 46 & 26 & 3.7 & 22 & 22 \\
\hline Rhine & 220 & 45 & 18 & 27 & 21 \\
\hline Rhone & 96 & 17 & 7.7 & 9.3 & 1.8 \\
\hline Tiber & 17 & 5.9 & 1.4 & 4.5 & 1.2 \\
\hline Po & 70 & 16 & 5.6 & 11 & 1.4 \\
\hline
\end{tabular}

The difference in northern and southern European rivers also can be seen with respect to nutrient flux. Although these is some scatter in the data, N$\mathrm{NO}_{3}$ fluxes from northern European rivers (open diamonds in Fig. 9) are generally 2 to 5 times greater than for similar sized rivers draining the south (solid dots in Fig. 9). In contrast, Scandinavian rivers have loads about an order of magnitude smaller for any given basin size. The exceptions to this general trend are Portuguese and Baltic state rivers (all of whom have low nitrate loads), the Rhone (whose load is much lower than similar sized southern rivers), and the Po (whose nitrate load is much higher than other southern rivers). Similar trends are seen for other nutrients, such as dissolved phosphate and silicate (data from Meybeck and Ragu, 1997.

\section{PAST AND FUTURE CHANGE}

As one can see from the preceding discussion, European rivers have been influenced by both the natural environment (climate and geology) and human activities. Deforestation, mining, industry, and urbanization, in fact, have played major roles in the water quality (or lack therefore) of European rivers and adjacent estuaries for many centuries, and, with reference to Mediterranean rivers, millenia (e.g., McNeil, 1992; Woodward, 1995). In fact, human impact on European river basins can be viewed on the basis of European history: rivers such

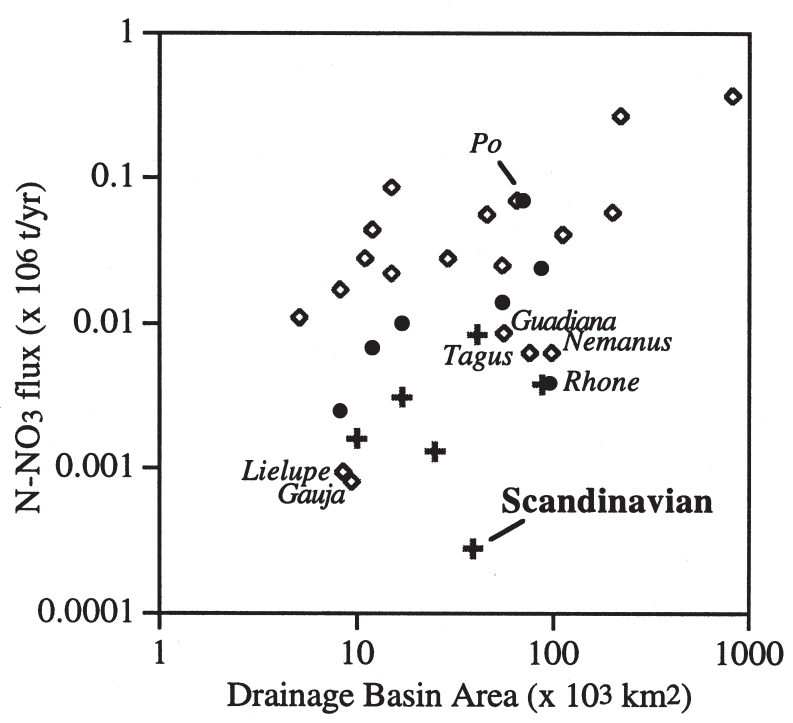

FIG. 9. - Dissolved $\mathrm{N}-\mathrm{NO}_{3}$ flux versus drainage basin area. Northern European rivers (open diamonds) generally have much greater loads than either southern European or Scandinavian rivers, the major exceptions being Portuguese and Baltic-state rivers, whose loads more closely approximate those found in Scandinavian rivers. Data calculated from data compiled by Meybeck and Ragu (1997).

as the Ebro, Po and Axios (Greece) were affected by human activity as early as 2500 years ago, but the Ebro and Po deltas prograded appreciably over the past 400 years in response to increased deforestation in the upper parts of the respective river basins (Mariño, 1992; Sestini, 1992).

In the past 50 years, however, sediment loads for many European rivers have decreased, in some cases precipitously, in response to both changes in 
land use and river diversion (most notably dam construction). Landuse has changed as western Europe has evolved increasingly to a non-agrian society. Frangipane and Paris (1994) reported more than an $85 \%$ decrease in sediment load for the Ombrone River (central western Italy) over the past century, which they explained by decreased grazing (by domestic animals) and a corresponding increased forest cover.

Dam construction, of course, has only added to the change in water and sediment flux. Spain alone has more than 900 large dams (defined by the International Commission on Large Dams as having a relief greater than $15 \mathrm{~m}$ ). Damming of the rivers in the latter part of the $20^{\text {th }}$ century not only has stopped delta-front progradation, it also has resulted in local erosion as well as landward intrusion of saline groundwaters. Becchi and Paris (1989; c.f. Billi and Rinaldi, 1997) estimated that the sediment load of the Arno River (Italy) increased from about $2 \times 10^{6} \mathrm{t} / \mathrm{yr}$ prior to the $16^{\text {th }}$ century to $7.5 \times 10^{6} \mathrm{t} / \mathrm{yr}$ in 1800 , but in the past 50 years has decreased to about $2.7 \times 10^{6} \mathrm{t} / \mathrm{yr}$, most of the rest being trapped behind dams. Three Albanian rivers (Drini, Vijose and Semani) formerly had an annual combined sediment load of about $75 \mathrm{x}$ $10^{6} \mathrm{t} / \mathrm{yr}$; but at present their combined load is about $26 \times 10^{6} \mathrm{t} / \mathrm{yr}$ (Ciavola et al., 1998). The examples of the Rhone and the Ebro are even more extreme, the former decreasing from 59 to about $6 \times 10^{6} \mathrm{t} / \mathrm{yr}$ (Pont, 1997) and the latter delivering less than $1 \%$ of its former load to the coastal zone (Guillén and Palaques, 1992). Moreover, the streambeds of many mountainous Mediterranean rivers have been increasingly mined for sand and gravel (even though this is often an illegal activity); the lower reaches of the Arno River, for instance, has been lowered as much as 2-4 m over the past century by river mining (Billi and Rinaldi, 1997).

Changes in the dissolved constituents flowing into European estuaries have been widely studied. Etchanchu and Probst (1988), for example, reported that a $14-19 \%$ increase in $\mathrm{Cl}^{-}, \mathrm{SO}_{4}^{-2}$, and $\mathrm{K}^{+-}$in the Garonne River between 1971 and 1984, and a 78\% increase in $\mathrm{NO}_{3}$ that was almost exclusively related to increased application of fertilizers in throughout the watershed.

As industrial and agricultural practices become more efficient and as human waste waters are more effectively treated, however, dissolved solid and nutrient contents should decline in many western
European rivers. It may take a bit longer for levels to fall in rivers draining former East-Bloc countries, but one can safely assume that within the next 20 years many (if not most) European rivers will discharge few suspended and dissolved solids than they do at present.

One result of these decreased fluxes should be decreased eutrophication of European estuaries and coastal waters. However, changing ratios of dissolved solids may change the composition of biological blooms in coastal waters. Humborg et al. (1997), for instance, found that a decreased flux of dissolved silicate from the Danube River (because of diatom blooms in various dammed lakes, chiefly the reservoir behind the Iron Gates Dam), which has resulted in a shift from a diatom-dominated phytoplankton community in the NW Black Sea to one dominated by dinoflagellates and coccolithorphorids. One implication of this ecosystem shift may be increased hypoxia and anoxia, as well as a greatly diminished coastal fisheries (Humborg et al., 1997).

Decreased sediment loads to the coastal zone already has resulted in increased erosion of the Ebro, Rhone and Po deltas (e.g., Mariño, 1992; Corre, 1992; Sestini, 1992), which presumably will only accelerate in the coming years. Similar accelerated erosion should occur along the Albanian coastline in response to decreased sediment loads from their rivers. Such effects, on the other hand, should be minimal for western and northern European rivers, as most of their watersheds already have been so completely "managed" that it seems highly improbable that their already tiny sediment loads can diminish much further. But to assume that one can use mid-20 th century values for any European river to estimate future (or even present-day) fluxes to adjacent coastal waters can lead to severe miscalculations. Care must be taken in using up-to-date values, even at a time when the number of rivers and stations being monitored appears to be decreasing (Vorosmarty et al., 2001).

\section{ACKNOWLEDGEMENTS}

I thank Katherine Farnsworth for her help in compiling many of the data used in this paper. Preparation of this paper was partly supported by research grants from the National Science Foundation (NSF) and the Office of Naval Research (ONR). 


\section{REFERENCES}

Becchi, I. and E. Paris. - 1989. Il corso dell'Arno e la sua evoluzione storica. Acqua Aria, 645-652.

Billi, P. and M. Rinaldi. - 1997. Human impact on sediment yield and channel dynamics in the Arno River basin (central Italy), IAHS Publ. 245: 301-311.

Ciavola, P., U. Tessari, F. Montovani and U. Simeoni. - 1998. Evaluation of floodplain changes and geomorphlogical mapping the coastal zone plain of Myzeq (Albania) using Landsat TM imagery. Ann. Geophysicae, 16(4): 1214.

Corre, J.-J. - 1992. Implications des changements climatiques étude de cas: le Golfe du Lion. In: L. Jeftic, J.D. Milliman, and G. Sestini (eds.), Climatic Change and the Mediterranean, pp. 328-427. Edward Arnold, London,

Etchanchu, D. and J.-L. Probst. - 1988. Evolution of the chemical composition of the Garonne River water during the period 1971-1984. Hydrol. Sci. J., 33: 243-256.

Frangipane, A. and E. Paris. - 1994. Long-term variability of sediment transport in the Ombrone River basin (Italy). IAHS Publ. 224: 317-324.

Fraser,A.S., M. Meybeck and E.D. Onglley. - 1995. Global Environmental Monitoring System (GEMS). Water Quality of World River Basins. UNEP Environment Library No. 14, 40 pp.

Guillén, J. and A. Palanques. - 1992. Sediment dynamics and hydrodynamics in the lower course of a river highly regulated by dams: the Ebro River. Sedimentol., 39: 567-579.

Hicks, D.M., J. Hill and U. Shankar. - 1996. Variation of suspended sediment yields around New Zealand: the relative importance of rainfall and geology. IAHS Publ. 236: 149-156.

Humborg, C., V. Ittekkot, A. Cociasu and B. von Bodungen. 1997. Effect of Danube River dam on Black Sea biogeochem- istry and ecosystem. Nature, 386: 385-388.

Larsen, R.L. and W.C. Pittman, III. - 1985. The Bedrock Geology of the World. W.H. Freeman and Company, Inc. New York (single map).

McNeil, J.R. - 1992. The Mountains of the Mediterranean World. Cambridge Univ. Press, $423 \mathrm{pp}$.

Mariño, M.G. - 1992. Implications of climatic change on the Ebro Delta. In: L. Jeftic, J.D. Milliman and G. Sestini (eds.), Climatic Change and the Mediterranean. Edward Arnold, London, 304-327.

Meybeck, M. and A. Ragu. - 1997. River discharges to the oceans: An assessment of suspended solids, major ions and nutrients. GEMS/EAP Report, 245 pp.

Milliman, J.D. and K.M. Farnsworth. - (in press). River Runoff, Erosion and Delivery to the Coastal Ocean: A Global Analysis. Oxford University Press.

Milliman, J.D. and J.P.M. Syvitski. - 1992. Geomorphic/tectonic control of sediment discharged to the ocean: the importance of small mountainous rivers. J. Geol., 100: 525-544.

Pont, D. - 1997. Les debits solides du Rhone a proximité de son embouchure donnees récentes (1994-1995). Rev. Geogr. Lyon, 72: 23-33.

Sestini, G. - 1992. Implications of climatic changes for the Po delta and Venice lagoon. In: L. Jeftic, J.D. Milliman and G. Sestini (eds.), Climatic Change and the Mediterranean. Edward Arnold, London, 428-494.

Vorosmarty, C.. et al. - 2001. Global water data: a newly endangered species. EOS, 82, 54-58.

Woodward, J.C. - 1995. Patterns of erosion and suspended sediment yield in Mediterranean river basins. In: I.D.L. Foster, A.M. Gurnell and B.W. Webb (eds), Sediment and Water Quality in River Catchments, pp 365-389. John Wiley \&, Chichester. 